\title{
COMBINED ANALYSIS OF LINKAGE AND WHOLE EXOME SEQUENCING REVEALS CIC AS A CANDIDATE GENE FOR ISOLATED DYSTONIA
}

\author{
BAĞLANTI VE TÜM EKZOM DIZILEME ANALIZLERININ BIRLIKTE \\ DEĞERLENDIRILMESIYLE CIC GENININ IZOLE DISTONI ADAYI OLARAK BELIRLENMESI
}

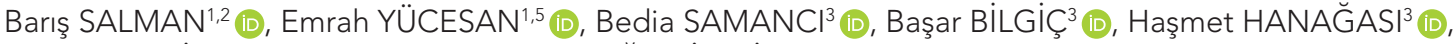

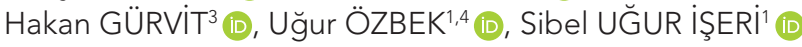
'Istanbul University, Aziz Sancar Institute of Experimental Medicine, Department of Genetics, Istanbul, Turkey ${ }^{2}$ Istanbul University, Graduate School of Health Sciences, Istanbul, Turkey ${ }^{3}$ Istanbul University, Istanbul Faculty of Medicine, Department of Neurology, Istanbul, Turkey ${ }^{4}$ Acibadem University, Faculty of Medicine, Department of Medical Genetics, Istanbul, Turkey ${ }^{5}$ Bezmialem Vakif University, Department of Medical Biology, Istanbul, Turkey

ORCID IDs of the authors: B.S. 0000-0002-7657-8576; E.Y. 0000-0003-4512-8764; B.S. 0000-0003-0667-2329; B.B. 0000-0001-6032-0856; H.H. 0000-0001-9645-7707; H.G. 0000-0003-2908-8475; U.Ö. 0000-0001-7031-3932; S.U.i. 0000-0002-5790-6853

Cite this article as: Salman B, Yucesan E, Samanci B, Bilgic B, Hanagasi H, Gurvit H, et al. Combined analysis of linkage and whole exome sequencing reveals cic as a candidate gene for isolated dystonia. J Ist Faculty Med 2021;84(4):457-63. doi: 10.26650/IUITFD.2021.913346

\section{ABSTRACT}

Objective: To explore the underlying genetic variations and mechanisms in a family affected by isolated dystonia.

Material and Method: We employed whole genome Single Nucleotide Polymorphism (SNP) based linkage analysis along with whole exome sequencing (WES) in a consanguineous family presenting with isolated dystonia. An in-house pipeline compiled for WES analysis along with in-depth in silico prediction algorithms were used to assess the associated data produced in this study. Sanger sequencing was used for variant confirmation and segregation.

Results: Data analysis included locus oriented WES variant prioritization and cryptic splicing predictions. We detected a homozygous and synonymous variation rs748449895 (NM_015125.4: c. $4143 \mathrm{C}>\mathrm{T}$; p. $($ Thr1381=)) in the capicua transcriptional repressor, CIC. This variation disrupts the YB-1 RNA recognition motif and creates an alternative SRp20 RNA recognition motif.

Conclusion: The resulting variant might cause the dystonia phenotype by affecting the alternative splicing of $\mathrm{CIC}$ transcript and altering the exon inclusion motif which may disrupt the ATXN1$\mathrm{CIC}$ complex.

Keywords: Autosomal recessive dystonia, whole genome genotyping, linkage analysis, whole exome sequencing, alternative splicing

\section{ÖZET}

Amaç: İzole distoni hastalığından etkilenmiş bir ailede hastalığa neden olan genetik varyasyonları ve mekanizmaları keşfetmek.

Gereç ve Yöntem: İzole distoni hastalığı tanısı konmuş ve akraba evliliği bulunan bir ailede, tüm genom Single Nucleotide Polymorphism (SNP) temelli bağlantı analizi ile beraber tüm ekzom dizileme (TED) gerçekleştirildi. TED analizleri için laboratuvarımızda geliştirilen akış hattı ve in siliko tahmin algoritmaları bu çalışmada üretilen verinin ilişkilendirilmesinde kullanıldı. Sanger dizileme varyantların doğrulanması ve ayrımı için kullanıldı.

Bulgular: SNP dizimi ile genotipleme, bağlantı analizi ve ekzom dizileme analizleri sonucu rs748449895 (NM_015125.4: c. 4143C > T; . $($ Thr1381=)) homozigot sinonim varyantı tespit edildi. Devamındaki biyoinformatik analizler varyantın YB-1 RNA tanıma motifi olduğunu gösterdi. Bu varyant YB-1 RNA tanıma motifini bozarak, SRp20 RNA tanıma motifi oluşturmaktadır.

Sonuç: Bulunan varyant, ekzon katılma motifini değiştirerek CIC transkriptinin alternatif kırpılmasını etkileyip ATXN1-CIC kompleksini bozarak distoni fenotipine yol açabilir.

Anahtar Kelimeler: Otozomal resesif distoni, tüm genom genotipleme, bağlantı analizi, tüm ekzom dizileme, alternatif kırpılma

Corresponding author/iletişim kurulacak yazar: sibel.ugur@istanbul.edu.tr

Submitted/Başvuru: 26.04.2021 • Revision Requested/Revizyon Talebi: 25.05.2021 •

Last Revision Received/Son Revizyon: 27.05.2021 • Accepted/Kabul: 28.05.2021 • Published Online/Online Yayın: 31.08 .2021 


\section{INTRODUCTION}

Dystonia is a group of movement disorders that is characterized by involuntary, chronic, twisting muscle contractions and which causes repetitive involuntary movements with temporary or permanent abnormal postures (1). It is a highly heterogeneous condition both in genetic and clinical dimensions (2). Nevertheless, a number of genes have been implicated in isolated dystonia, including THAP1, GNAL, ANO3 and TOR1A $(3,4)$.

Linkage analysis is an old, but still useful and reliable approach to map the chromosomal coordinates of disease genes, particularly in extended families with monogenic conditions (5). This method has had a tremendous impact on autosomal recessive conditions in consanguineous families. In today's reality, where next generation sequencing (NGS) techniques seem to be the gold standard for disease gene identification, linkage analysis still has a role to serve: Linkage analysis pinpoints candidate chromosomal regions as localization filters for NGS data analysis. In this way, instead of evaluating a large number of samples and variants with unknown significance, a limited number of patients with targeted variants can be examined $(6,7)$. Whole exome sequencing (WES) is a popular tool among all NGS approaches because of its relatively low variant content and easy to handle analysis features compared to whole genome applications (8). Therefore, in the last decade there have been several reports that have combined linkage analysis with WES as a powerful tool to determine genes and variants associated with the specific diseases (9-11).

Herein, we present genetic studies including Single Nucleotide Polymorphism (SNP) array based linkage analysis and WES performed in a first degree consanguineous family from Turkey with three patients afflicted with isolated dystonia. This effort has led us to identify a novel variation that possibly disrupts an alternative splicing motif in $\mathrm{CIC}$.

\section{MATERIAL AND METHOD}

In this study, a first degree consanguineous family from Turkey with three affected (Case 1, Case 2, Case 4) and one unaffected (Case 3) siblings along with their mother (Case 5) were evaluated. Clinical assessment was performed at Istanbul University, Faculty of Medicine, Behavioral Neurology and Movement Disorders Unit of the Neurology Department, Istanbul, Turkey. Physical and neurological examinations were performed for all available family members and detailed information on family history was collected. Informed consents were obtained from all five family members in accordance with Istanbul University, Istanbul Faculty of Medicine, Clinical Ethics Committee with consent certificate 2015/493 approved on 23/02/2015. The clinical features of the patients are compiled in Table 1.

DNA was extracted using the QIAamp DNA Blood Maxi Kit (Qiagen $\mathrm{GmbH}$, Hilden, Germany) according to the manufacturer's protocol. Afterwards, whole genome genotyping was performed for all five individuals using the Illumina HumanCytoSNP-12v2-1 300k BeadChip kit. Firstly, copy number variations (CNVs) were analyzed using Illumina GenomeStudio v2.0 using cnvPartition CNV Analysis Plugin v3.2.1. PLINK Input Report Plug-in v2.1.4 is used to convert the data to a text format for linkage analysis. Multipoint logarithm of the odds (LOD) score was calculated using GeneHunter v.2.1r5 (12) and run under EasyLinkage v5.08 (13) interphase assuming reces-

Table 1: Clinical characterization of affected siblings

\begin{tabular}{llll}
\hline & Case 1 & Case 2 & Case 4 \\
Sex & M & F & F \\
Age at onset (year) & 7 & 9 & 7 \\
First detectable sign & Tremor & Tremor & Dysarthria, dysphagia, gait \\
& & difficulty \\
Age at last examination & 53 & 42 & 53 \\
Progression & Yes & Yes & Yes \\
Pyramidal signs & Brisk reflexes & No & No \\
Oculomotor findings & Normal & Normal & Normal \\
ENMG study & Mild myopathic changes & Normal & N/A \\
MRI findings & Unremarkable & Unremarkable & N/A \\
Other findings & $\begin{array}{l}\text { Dysarthria, dysphagia, } \\
\text { dystonic tremor, axial } \\
\text { dystonia, chorea, mild } \\
\text { asymmetric bradykinesia }\end{array}$ & $\begin{array}{l}\text { Dysarthria, dysphagia, } \\
\text { dystonic tremor, axial } \\
\text { dystonia, oromandibular } \\
\text { dystonia, ataxia }\end{array}$ & Dystonia \\
\hline
\end{tabular}


sive inheritance with full penetrance. Computation was adjusted in sets of 100 markers and spacing $0.1 \mathrm{cM}$. In addition, Haplopainter v1.043 (14) was used to draw the pedigree diagram and visualize the resulting haplotypes.

Whole exome sequencing was performed for the two affected siblings (Case 2 and Case 4) from the family on an Illumina HiSeq2000 platform. Exonic DNA was captured using Agilent SureSelect Human All Exon V5 (Agilent Technologies, Santa Clara, CA, USA). Samples were sequenced for the targeted regions with a mean coverage of $53 \times$ and $88 \%$ of the reads were covered over $20 \times$. Alignment to reference genome hg19 was done using Burrows-Wheeler Aligner v0.7.16a (15), sorting, marking duplicate reads and other bam manipulations were carried out using Picard tools v2.12.0 (16), variant calling was performed with the Genome Analysis Toolkit v3.6.0 HaplotypeCaller (17). The variants were annotated using the Ensembl Variant Effect Predictor (VEP) v101 (18). Variants with gnomAD and $1 \mathrm{kG}$ allele frequency less than 0.001 were filtered using VEP filter script. Filtering of the high LOD regions shared by two siblings was performed using python v3.9 script. Validation and segregation analyses for candidate variants were carried-out using Sanger sequencing. SpliceAid 2 and Splice Al were used to predict the splicing impacts of these variations $(19,20)$.

\section{RESULTS}

A consanguineous family with four siblings and their mother were studied. Three of the siblings (two of which were female and one was male), were affected and the other sibling was unaffected. All the affected siblings (Case 1, Case 2, Case 4), the unaffected sibling (Case 3), and the mother (Case 5), were examined at the Department of Neurology at Istanbul University Faculty of Medicine. Case 1 was admitted to our clinic at the age of 49 for the first time due to dystonia and involuntary movements in the whole body. He started having tremors in his right hand at the age of seven, and after two years, he also had tremor in his left hand, and his writing had gradually deteriorated. At the age of 12, gait difficulty started, and at the age of 15 , he had dystonia in his whole body, mostly in his waist and neck, and rarely dysphagia. His complaints increased in cold and crowded environments. He had no other diagnosed diseases. His parents were cousins. He was the second of four siblings, and his two sisters had similar complaints (Case 2, Case 4). In his examination, he was disorientated, and his speech was dysarthric. Myerson was positive. There were diffuse dystonic and choreiform movements, (these were more prominent on the right side of the body), and dystonic tremors in the bilateral upper extremity. There was bilateral mild bradykinesia which was more prominent on the left side. Deep tendon reflexes were brisk. He had gait difficulty due to severe dystonia in the whole body. Cranial MRI and EEG examinations were normal. EMG and muscle biopsy revealed mild myopathic changes. Serum and urine copper and serum ceruloplasmin levels were normal. Ophthalmic examination was unremarkable. Bilateral p100 latencies were prolonged in the visual evoked potential test. Genetic investigation for Huntington's disease was negative. Despite the L-dopa, clonazepam, biperiden, baclofen, tetrabenazine and bornaprine treatments, his complaints were ongoing in his last examination at the $4^{\text {th }}$ year of his follow-up. Case 2 was admitted to our clinic for the first time at the age of 38 with gait difficulty, tremors in the hands, and speech disorder. At the age of nine, she first started having tremors in her right hand and, after a while, in her left hand, and deterioration in writing was observed. Ten years later, speech and swallowing disturbances were added, and ten years later, ataxia and gait difficulties were observed. Her past medical history was unremarkable. Her speech was dysarthric in the neurological examination. There were oromandibular dystonia and bilateral upper extremity dystonic tremor, more prominent on the right. She had gait difficulty due to ataxia. Vitamin E and serum AFP levels were normal. Cranial MRI and EMG were unremarkable. The neurological examination findings of the patient, who did not attend follow-up examinations regularly and did not respond to L-dopa treatment, were the same in the $4^{\text {th }}$ year follow-up. Case 4 , who was admitted for the first time at the age of 53, had gradually progressing gait, speech, and swallowing difficulty, which started at the age of seven. The patient, who had dysarthria, generalized dystonia, and was unable to walk due to dystonia at the first examination, did not attend maintain their examinations. The unaffected sibling (Case 3) and the mother (Case 5) had no neurological complaints, and neurological examinations were normal.

Evaluation of CNVs using the SNP data did not suggest a shared CNV event in the affected siblings. Parametric linkage analysis in the family identified seven linkage peaks on chromosomes 1, 3, 4, 6, 10, 11 and 19, respectively with a maximum LOD score of higher than 2.5 (Figure 1). These coordinates (Table 2) were prioritized for WES

Table 2: Chromosomal positions (hg19) of regions with LOD score over 2.5

\begin{tabular}{lcc}
\hline Chromosome & Start & End \\
chr1 & 94023997 & 110579200 \\
chr3 & 150872381 & 153042330 \\
chr4 & 140021705 & 140672561 \\
chr6 & 133528828 & 134365722 \\
chr10 & 117763432 & 120364746 \\
chr11 & 59716220 & 84908270 \\
chr19 & 33538792 & 43404463 \\
\hline
\end{tabular}



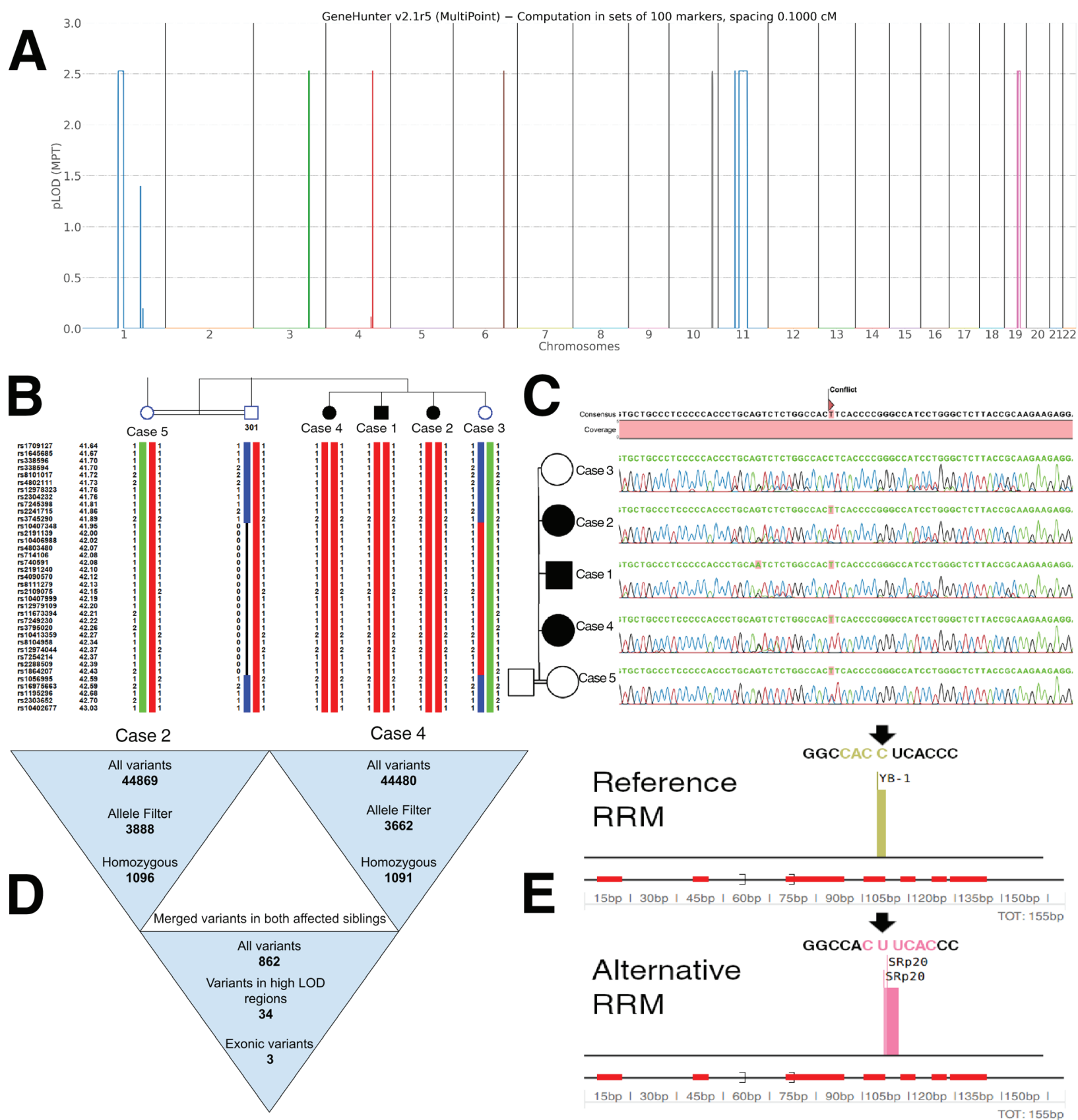

Contlic

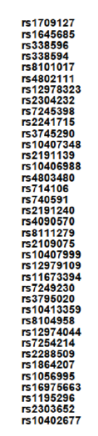

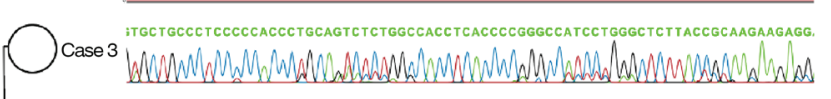

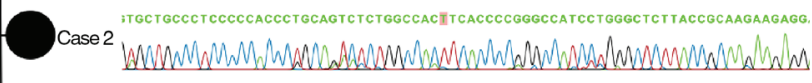

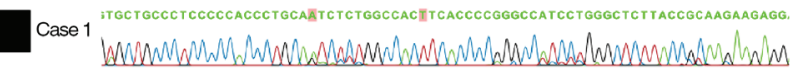

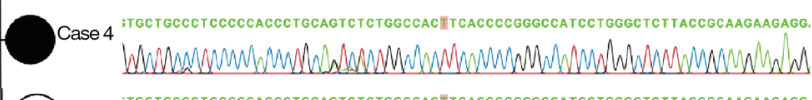

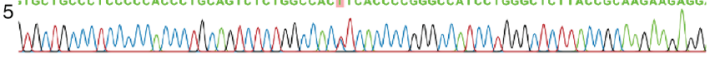

\section{Reference RRM}

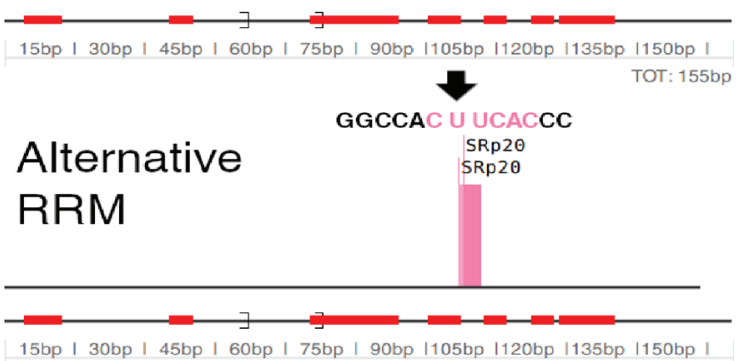

Figure 1: Genetic studies in the dystonia family. A) Multipoint LOD scores (GeneHunter) of the SNP data set along the autosomal chromosomes, B) SNP derived haplotype blocks (Haplopainter) on chromosome 19 around CIC gene, C) Segregation of the variant NM 015125.4:c.4143C>T within the family, D) Summary of the filtering steps to discover candidate variants, E) In-silico prediction (Splice Aid 2) analysis to show possible alternative splicing effect of the variant

analysis. Filtering process started with the evaluation of these regions and then continued with successive steps as presented in Figure 1. This filtering strategy led us to identify three synonymous candidate variants as annotated with VEP and presented in Table 3. None of these variants were present in the homozygous form in the gnomAD database. Among these genes, Capicua transcriptional
repressor-ClC encodes a member of high mobility groupbox (HMG-box) superfamily of transcriptional repressors and has shown to be a critical regulator of neuronal differentiation (21). Although the variant was annotated as synonymous with the VEP pipeline, the role of $\mathrm{CIC}$ gene product in neuronal differentiation has prompted us to perform familial variant segregation and in depth in sili- 
Table 3: Remaining variants as result of the filtering strategy

\begin{tabular}{|c|c|c|c|c|}
\hline & Position (hg19/hg38) & Gene Consequence & $\begin{array}{l}\text { HGVSc } \\
\text { HGVSp }\end{array}$ & $\begin{array}{l}\text { Existing variation } \\
\text { GnomAD_AF }\end{array}$ \\
\hline 1 & $\begin{array}{l}\text { chr11:g.73021267T>A } \\
\text { chr11:g.73310222T>A }\end{array}$ & $\begin{array}{l}\text { ARHGEF17 } \\
\text { synonymous_variant }\end{array}$ & $\begin{array}{l}\text { NM_014786.3:c.1584T>A } \\
\text { NP_055601.2:p.Pro528= }\end{array}$ & rs553216026 \\
\hline 2 & $\begin{array}{l}\text { chr19:g.36431638G >A } \\
\text { chr19:g.35940736G >A }\end{array}$ & $\begin{array}{l}\text { LRFN3 } \\
\text { synonymous_variant }\end{array}$ & $\begin{array}{l}\text { NM_024509.1:c.1311G>A } \\
\text { NP_078785.1:p.Gly437= }\end{array}$ & $\begin{array}{l}\text { rs } 144242723 \\
0.0008631\end{array}$ \\
\hline 3 & $\begin{array}{l}\text { chr19: } 9.42798189 C>T \\
\text { chr19:9.42294037C>T }\end{array}$ & $\begin{array}{l}\mathrm{ClC} \\
\text { synonymous_variant }\end{array}$ & $\begin{array}{l}\text { NM_015125.5:c.4143C>T } \\
\text { NP_055940.3:p.Thr1381= }\end{array}$ & $\begin{array}{c}\text { rs748449895 } \\
0.00004778\end{array}$ \\
\hline
\end{tabular}

co analyses. Sanger sequencing of this variant along with haplotype inspection of the linkage region confirmed segregation of ENST00000575354.6:c.4143C > T with the phenotype in the pedigree (Figure 1). According to in silico prediction tool SpliceAid 2 (19), the variant causes disruption of the existing RNA recognition motif (RRM) and creates a new different RRM (Figure 1). SpliceAl tool also predicts a minor acceptor loss effect (20).

\section{DISCUSSION}

Using two unbiased genetic approaches, SNP based linkage analysis and WES, we identified a variation that possibly affects an alternative splicing motif in the $\mathrm{ClC}$ gene that may be associated with dystonia. The $\mathrm{ClC}$ gene is a human ortholog of the Drosophila melanogaster capicua gene and belongs to the protein family of the high mobility group (HMG)-box superfamily of transcriptional repressors. Protein capicua homolog plays a role in development of the central nervous system (CNS) and is involved with brain development with ataxin-1 (22). $\mathrm{ClC}$ is known to form a transcriptional repressor complex with ATXN1 which was previously demonstrated to cause several neurological diseases (23). Dystonias are a heterogeneous group of disorders as mentioned above. Dystonias may be classified according to the affected body part, e.g. focal, segmental, multifocal, hemidystonia and generalized. Furthermore, dystonias may also be classified by associated features, such as isolated, combined and complex (24). The most recent classifications of dystonias are recommended by the European Federation of Neurological Societies (25). Taken together, dystonias are clinically and genetically complex, which complicates gene identification studies. However, it may be possible to identify candidate genes in pedigrees with clear autosomal recessive inheritance caused by identical descent inheritance due to consanguinity. Recently, a number of dystonia related genes have been identified in parallel with the developments in NGS technologies, such as CIZ1, ANO3, TUBB4A and GNAL for primary dystonia, PRRT2 for paroxysmal kinesigenic dystonia, and some other genes, SLC30A10 and ATP1A3 (26). Both dominant and recessive inheritance patterns are valid for genetic dystonias (27). Among the studies with autosomal reces- sive patterns, some patients have been reported in which the parents were consanguineous $(28,29)$.

Our study demonstrates a synonymous variation in $\mathrm{CIC}$. This variation resides on the exon 17 of ENST00000575354.6 (NM_015125.5), which consists of 20 exons in total. Interestingly, it has been shown that dominantly affecting variations in $\mathrm{ClC}$ may cause intellectual disability (23). Likewise, in 2010, Vissers et al. demonstrated a heterozygous de novo missense variation (23, 30). In 2011 Bettegowda et al. reported $\mathrm{ClC}$ gene variations in six cases in their study on human oligodendroglioma (31). When considered overall, variations in the $\mathrm{ClC}$ gene exhibit autosomal recessive character. However, evaluating the nature and genetic heterogeneity of the disease, it should be considered that different inheritance patterns can be seen.

Although the homozygous variant detected herein is synonymous, our in depth in silico analyses have shown that this variation breaks the existing YB-1 RRM (GGCCACCUCACCC) (32) and creates a new motif (GGCCACUUCACCC), which is recognized by SRp20 splicing factor (33). YB-1 transcription factor is shown to stimulate exon inclusion while SRp20 stimulates the splicing of the exon $(32,34)$. Consequently, this apparently 'silent' variation may not be silent at the end of the day: It may result in cryptic splicing via recruitment of the SRp20 splicing factor. It is very well known that alternative splicing is an important mechanism that confers protein diversity and alterations in control of splicing may be associated with disease (35-37). Several genetic diseases which are molecularly undiagnosed have turned out to be associated with cryptic splicing due to 'silent' exonic or intronic variations that actually affect pre-mRNA splicing $(38,39)$. Some well characterized neurological diseases, such as frontotemporal dementia, parkinsonism, spinocerebellar ataxia 8 are thought to be associated with abnormal splicing, but the exact evidence is still unclear (40). Licatalosi et al. compiled neurological diseases, including ataxia-telangiectasia, myotonic dystrophy, FXTAS, SMA, SCA2-8-10-12 that are directly related to alternative splicing defects (41). After these findings, in 2013 Feng and Xie described different mechanisms of alternative splic- 
ing that are related to neurological diseases (42). Alternative splicing variants are also shown to be a part of the disease mechanisms of neurological disorders with complex genetic etiologies including ataxia and dystonia $(43,44)$. In sum, although the mechanism of occurrence of many neurological diseases has been reported to be alternative splicing, there may be other many neurological diseases that are still not clarified.

\section{CONCLUSION}

In our findings we demonstrated that $\mathrm{CIC}$ may be associated with dystonia and other neurological phenotypes by mechanism of alternative splicing. Therefore, our report requires further functional studies both for in vitro and in vivo to define the exact features of the CIC gene.

Ethics Committee Approval: This study was approved by the Clinical Ethical Committee of the Istanbul University, Istanbul Faculty of Medicine (Date: 23/02/2015, No: 2015/493).

Informed Consent: Written consent was obtained from the participants.

Peer Review: Externally peer-reviewed.

Author Contributions: Conception/Design of Study- B.S., S.U.I., E.Y., B.B., H.H.; Data Acquisition- E.Y., B.S., B.B., H.H., H.G.; Data Analysis/Interpretation- B.S., E.Y., B.S., B.B., H.H., S.U.i.; Drafting Manuscript- B.S., E.Y., B.S., B.B., S.U.I.; Critical Revision of Manuscript- B.S., E.Y., B.S., B.B., H.H., H.G., U.Ö., S.U.I.; Final Approval and Accountability- B.S., E.Y., B.S., B.B., H.H., H.G., U.Ö., S.U.i

Conflict of Interest: Authors declared no conflict of interest.

Financial Disclosure: This study was supported by the grants of Scientific Research Projects Coordination Unit of Istanbul University (Project numbers: TYL-2018-30315 and ONAP-11021). EY and BS had been fellows of TUBITAK-113S331 and TUBITAK-214S222 projects.

Acknowledgement: The authors are grateful to the family for participating in this study. We also thank to Turkish Academy of Sciences for the 2019 Distinguished Young Scientist Award to SAUI.

Etik Komite Onayı: Bu çalışma için etik komite onayı İstanbul Üniversitesi, İstanbul Tıp Fakültesi Klinik Etik Kurulu'ndan alınmıştır (Tarih: 23/02/2015, No: 2015/493).

Bilgilendirilmiş Onam: Katılımcılardan bilgilendirilmiş onam alınmıştır.

\section{Hakem Değerlendirmesi: Dış bağımsız.}

Yazar Katkıları: Çalışma Konsepti/Tasarım- B.S., S.U.I., E.Y., B.B., H.H.; Veri Toplama- E.Y., B.S., B.B., H.H., H.G.; Veri Analizi/Yorumlama- B.S., E.Y., B.S., B.B., H.H., S.U.I.; Yazı Taslağı- B.S., E.Y.,
B.S., B.B., S.U.I..; İçeriğin Eleştirel İncelemesi- B.S., E.Y., B.S., B.B., H.H., H.G., U.Ö., S.U.i.; Son Onay ve Sorumluluk- B.S., E.Y., B.S., B.B., H.H., H.G., U.Ö., S.U.i

Çıkar Çatışması: Yazarlar çıkar çatışması beyan etmemişlerdir.

Finansal Destek: Bu çalışma, İstanbul Üniversitesi Bilimsel Araştırma Projeleri Koordinasyon Birimi'nin hibeleri ile desteklenmiştir (Proje numaraları: TYL-2018-30315 ve ONAP-11021). EY ve BS, TÜBITAK-113S331 ve TÜBITAK-214S222 projelerinin bursiyeriydi.

Teşekkür: Yazarlar, bu çalışmaya katıldığı için aileye minnettardır. SAUI'ye verilen 2019 Seçkin Genç Bilim İnsanı Ödülü için Türkiye Bilimler Akademisi'ne de teşekkür ederiz.

\section{REFERENCES}

1. Jinnah HA. Diagnosis \& Treatment of dystonia. Neurol Clin 2015;33(1):77-100. [CrossRef]

2. Balint B, Mencacci NE, Valente EM, Pisani A, Rothwell J, Jankovic J, et al. Dystonia. Nature Reviews Disease Primers. 2018;4(1):1-23. [CrossRef]

3. Domingo A, Yadav R, Ozelius LJ. Isolated dystonia: clinical and genetic updates. J Neural Transm (Vienna) 2021;128(4):405-16. [CrossRef]

4. Charlesworth G, Bhatia KP, Wood NW. The genetics of dystonia: new twists in an old tale. Brain 2013;136(Pt 7):2017-37. [CrossRef]

5. Pulst SM. Genetic linkage analysis. Arch Neurol 1999;56(6):667. [CrossRef]

6. Yucesan E, Ugur Iseri SA, Bilgic B, Gormez Z, Bakir Gungor $B$, Sarac A, et al. SYNE1 related cerebellar ataxia presents with variable phenotypes in a consanguineous family from Turkey. Neurol Sci 2017;38(12):2203-7. [CrossRef]

7. Ugur Iseri SA, Yucesan E, Tuncer FN, Calik M, Kesim Y, Altiokka Uzun G, et al. Biallelic loss of EEF1D function links heat shock response pathway to autosomal recessive intellectual disability. Journal of Human Genetics 2019;64(5):421-6. [CrossRef]

8. Zech M, Jech R, Boesch S, Škorvánek M, Weber S, Wagner $M$, et al. Monogenic variants in dystonia: an exome-wide sequencing study. The Lancet Neurology 2020;19(11):90818. [CrossRef]

9. Mulder R, Lisman T, Meijers JCM, Huntington JA, Mulder $A B$, Meijer K. Linkage analysis combined with whole-exome sequencing identifies a novel prothrombin (F2) gene mutation in a Dutch Caucasian family with unexplained thrombosis. 1. 2020;105(7):e370-2. [CrossRef]

10. Mescheriakova JY, Verkerk AJ, Amin N, Uitterlinden AG, van Duijn CM, Hintzen RQ. Linkage analysis and whole exome sequencing identify a novel candidate gene in a Dutch multiple sclerosis family. Mult Scler 2019;25(7):90917. [CrossRef]

11. Choi YJ, Ohn JH, Kim N, Kim W, Park K, Won S, et al. Family-based exome sequencing combined with linkage analyses identifies rare susceptibility variants of MUC4 for gastric cancer. PLOS ONE 2020;15(7):e0236197. [CrossRef]

12. Markianos K, Daly MJ, Kruglyak L. Efficient multipoint linkage analysis through reduction of inheritance space. The American Journal of Human Genetics 2001;68(4):96377. [CrossRef] 
13. Hoffmann K, Lindner TH. easyLINKAGE-Plus-automated linkage analyses using large-scale SNP data. Bioinformatics 2005;21(17):3565-7. [CrossRef]

14. Thiele H, Nürnberg P. HaploPainter: a tool for drawing pedigrees with complex haplotypes. Bioinformatics 2005;21(8):1730-2. [CrossRef]

15. Li H, Durbin R. Fast and accurate short read alignment with Burrows-Wheeler transform. Bioinformatics 2009;25(14):1754-60. [CrossRef]

16. A set of command line tools (in Java) for manipulating high-throughput sequencing (HTS) data and formats such as SAM/BAM/CRAM and VCF.: broadinstitute/picard [Internet]. Broad Institute; 2019 [cited 2019 May 7]. Available from: https://github.com/broadinstitute/picard

17. McKenna A, Hanna M, Banks E, Sivachenko A, Cibulskis K, Kernytsky A, et al. The Genome Analysis Toolkit: a MapReduce framework for analyzing next-generation DNA sequencing data. Genome Res 2010;20(9):1297-303. [CrossRef]

18. McLaren W, Gil L, Hunt SE, Riat HS, Ritchie GRS, Thormann $A$, et al. The ensembl variant effect predictor. Genome Biology 2016;17(1):122. [CrossRef]

19. Piva F, Giulietti M, Burini AB, Principato G. SpliceAid 2: a database of human splicing factors expression data and RNA target motifs. Hum Mutat 2012;33(1):81-5. [CrossRef]

20. Jaganathan K, Panagiotopoulou SK, McRae JF, Darbandi SF, Knowles D, Li Yl, et al. Predicting splicing from primary sequence with deep learning. Cell 2019;176(3):535-548.e24. [CrossRef]

21. Inah Hwang, Heng Pan, Yao J, Olivier Elemento, Hongwu Zheng, Paik J. ClC is a critical regulator of neuronal differentiation. JCl Insight [Internet]. 2020 [cited 2021 Feb 22];5(9). Available from: https://insight.jci.org/articles/ view/135826 [CrossRef]

22. Lee C-J, Chan W-I, Cheung M, Cheng Y-C, Appleby VJ, Orme AT, et al. CIC, a member of a novel subfamily of the HMG-box superfamily, is transiently expressed in developing granule neurons. Brain Res Mol Brain Res 2002;106(1-2):151-6. [CrossRef]

23. Lu H-C, Tan Q, Rousseaux MWC, Wang W, Kim J-Y, Richman $\mathrm{R}$, et al. Disruption of the ATXN1-CIC complex causes a spectrum of neurobehavioral phenotypes in mice and humans. Nature Genetics 2017;49(4):527-36. [CrossRef]

24. Klein C, Lohmann K, Marras C, Münchau A. Hereditary Dystonia Overview. In: Adam MP, Ardinger HH, Pagon RA, Wallace SE, Bean LJ, Mirzaa G, et al., editors. GeneReviews ${ }^{\circledR}$ [Internet]. Seattle (WA): University of Washington, Seattle; 1993 [cited 2021 Feb 14]. Available from: http://www.ncbi. nlm.nih.gov/books/NBK1155/

25. Albanese A, Asmus F, Bhatia KP, Elia AE, Elibol B, Filippini $G$, et al. EFNS guidelines on diagnosis and treatment of primary dystonias. Eur J Neurol 2011;18(1):5-18. [CrossRef]

26. Charlesworth G, Bhatia KP, Wood NW. The genetics of dystonia: new twists in an old tale. Brain 2013;136(Pt 7):2017-37. [CrossRef]

27. Németh $\mathrm{AH}$. The genetics of primary dystonias and related disorders. Brain 2002;125(Pt 4):695-721. [CrossRef]
28. Almasy L, Bressman SB, Raymond D, Kramer PL, Greene $P E$, Heiman GA, et al. Idiopathic torsion dystonia linked to chromosome 8 in two Mennonite families. Ann Neurol 1997;42(4):670-3. [CrossRef]

29. Ozelius LJ, Bressman SB. Genetic and clinical features of primary torsion dystonia. Neurobiol Dis 2011;42(2):127-35. [CrossRef]

30. Vissers LELM, de Ligt J, Gilissen C, Janssen I, Steehouwer M, de Vries $\mathrm{P}$, et al. A de novo paradigm for mental retardation. Nat Genet 2010;42(12):1109-12. [CrossRef]

31. Bettegowda C, Agrawal N, Jiao Y, Sausen M, Wood LD, Hruban $\mathrm{RH}$, et al. Mutations in $\mathrm{CIC}$ and FUBP1 contribute to human oligodendroglioma. Science 2011;333(6048):1453-5. [CrossRef]

32. Wei WJ, Mu SR, Heiner M, Fu X, Cao LJ, Gong XF, et al. YB-1 binds to CAUC motifs and stimulates exon inclusion by enhancing the recruitment of U2AF to weak polypyrimidine tracts. Nucleic Acids Res 2012;40(17):8622-36. [CrossRef]

33. Hargous $Y$, Hautbergue GM, Tintaru AM, Skrisovska L, Golovanov AP, Stevenin J, et al. Molecular basis of RNA recognition and TAP binding by the SR proteins SRp20 and 9G8. EMBO J 2006;25(21):5126-37. [CrossRef]

34. Änkö ML, Morales L, Henry I, Beyer A, Neugebauer KM. Global analysis reveals SRp20- and SRp75-specific mRNPs in cycling and neural cells. Nature Structural \& Molecular Biology. 2010;17(8):962-70. [CrossRef]

35. Tazi J, Bakkour N, Stamm S. Alternative splicing and disease. Biochim Biophys Acta. 2009;1792(1):14-26. [CrossRef]

36. Webster NJG. Alternative RNA splicing in the pathogenesis of liver disease. Front Endocrinol (Lausanne).;8:133. [CrossRef]

37. Kremer LS, Bader DM, Mertes C, Kopajtich R, Pichler G, luso A, et al. Genetic diagnosis of Mendelian disorders via RNA sequencing. Nature Communications 2017;8(1):15824. [CrossRef]

38. Poulos MG, Batra R, Charizanis K, Swanson MS. Developments in RNA splicing and disease. Cold Spring Harb Perspect Biol 2011;3(1):a000778. [CrossRef]

39. Cartegni L, Chew SL, Krainer AR. Listening to silence and understanding nonsense: exonic mutations that affect splicing. Nature Reviews Genetics 2002;3(4):285-98. [CrossRef]

40. Dredge BK, Polydorides AD, Darnell RB. The splice of life: alternative splicing and neurological disease. Nat Rev Neurosci 2001;2(1):43-50. [CrossRef]

41. Licatalosi DD, Darnell RB. Splicing regulation in neurologic disease. Neuron 2006;52(1):93-101. [CrossRef]

42. Feng $D$, Xie J. Aberrant splicing in neurological diseases. Wiley Interdiscip Rev RNA 2013;4(6):631-49. [CrossRef]

43. Shohet A, Cohen L, Haguel D, Mozer Y, Shomron N, Tzur $\mathrm{S}$, et al. Variant in SCYL1 gene causes aberrant splicing in a family with cerebellar ataxia, recurrent episodes of liver failure, and growth retardation. European Journal of Human Genetics 2019;27(2):263-8. [CrossRef]

44. Xiao J, Zhao Y, Bastian RW, Perlmutter JS, Racette BA, Tabbal SD, et al. Novel THAP1 sequence variants in primary dystonia. Neurology 2010;74(3):229-38. [CrossRef] 